\title{
The Course Orientation of Electronic Technology in the Secondary Vocational Education System
}

\author{
Xiaoyu Liu, Shixin Li *(corresponding author), Yang Cao \\ Tianjin University of Technology and Education, Tianjin 300222, China
}

\begin{abstract}
Since the reform and opening up, electronic technology has been developing steadily for several decades and permeated lots of fields of society. It can be captured the shadow of electronic technology in the fields of medical treatment, machinery manufacturing and information processing. This is an urgent need to cultivate a large number of relevant technical personnel. The secondary vocational and technical schools are the main places for us to train front-line workers. In modern society, the new vocational education system has put forward new requirements for the curriculum orientation of the secondary vocational education system. The original curriculum system can no longer meet the rapid development of society and the progress of science and technology. Therefore, it is necessary to define the course positioning of electronic technology in the education system. Based on the analysis of the problems in the implementation of the secondary vocational education curriculum, this paper deeply analyzes the curriculum orientation of the subject of electronic technology and puts forward corresponding strategies, thus to promote the vocational education curriculum reform put forward the constructive suggestions.
\end{abstract}

Keywords-Vocational education; Electronic technique; Curriculum reform; School-enterprise cooperation

\section{INTRODUCTION}

The course of electronic technology is obviously different from the general knowledge course that students study in junior middle school. General knowledge course teaching mainly focus on teaching scientific and cultural knowledge, laying solid foundation theory emphatically. [1] The electronic technology course in nature belongs to the course of practical. Not only focus on the basic theory, but also need personal practice. It is also the obvious difference in the nature of the course. The students' learning places are not limited to the classroom, but they also need to go to the training base to learn and experiment.

At home and abroad, there have been many successful examples of teaching reform of education, but any kind of reform should be adjusted according to its own characteristic. In order to make the reform more adaptable to the characteristics of students in secondary vocational and technical schools in our country, and to integrate the socialist characteristics of our country, we will further explore and study the teaching methods, curriculum arrangement and assessment system of electronic technology courses. In this for electronic technology course teaching methods, curriculum and assessment system for further discussion and research.

\section{OPTIMIZE COURSE DESIGN AND ADJUST CLASS} STRUCTURE

Most students in the electrical and electronics majors have not been exposed to electronic technology before the senior high school entrance examination. From high school to technical school, they can be said to be a zero foundation in professional knowledge. But students who chose this major, mostly has a strong interest in the electronic technology. Interest is an important key to opening the door to exploration. Therefore, in the course design process, it is necessary to pay attention to the students' strong interest in electronic technology. On the basis of protecting the students' curiosity, the proportion of course should be allocated reasonably. Avoid the mental tiredness caused by the over-complicated and heavy task. Theoretical courses can be intersected with practical training courses. It can avoid the students' operating ability cannot be well practiced caused by the long theoretical study. In secondary vocational schools, students fall into two categories: one is for the purpose of promotion and the other is to become an excellent technical worker after graduation. [2] Students aiming for higher education should take into account both cultural and professional courses, and the students who will become technical workers should focus on specialized courses and professional skills. In current vocational education development situation, there are still some schools out of the education concept of "learning by doing". These schools' students pure learning theory, neglecting practice. They spend a lot of time to study textbook more esoteric theoretical knowledge and ignores the integration of theory with practice, this also caused extensive concern of society and school. It is very significant to adjust the class structure properly. So, how to arrange the proportion of professional courses is a question that the school must consider carefully.

\section{IMPROVE THE APPRAISAL SYSTEM AND IMPROVE THE TEACHING EFFICIENCY}

Under the influence of the traditional education system, the assessment system of the secondary vocational schools mainly focuses on standardized tests. [3]The students take the examination and the teachers grade the examination papers. By this kind of assessment system, students' professional knowledge can be well quantified. But it can not reflect the students' operational ability and comprehensive ability. So, it is necessary to inspect students' operational ability regularly, which is conducive to understanding the students' receptivity and the development of operation ability in the current learning 
stage. Teachers should also strive to improve their own quality, make the teaching and learning to better fit together. In the process of examination, skill examination should be equal to standardized test set strict standards, should not be ignored. Setting up reasonable exam content, combining skill examination contents and practical principles. Exams should select that helps students to better understand the content of knowledge, thereby improving their ability. Written examination should also follow the principle of practicality, combined with the high quality teaching material reasonable set tests. Final purpose is to make the test can reflect students' learning situation and help students consolidate what they have learned at this stage. Teachers can also be based on students' examination situation, adjust the teaching target. In addition, in the context of school-enterprise cooperation, the school can appropriately take some enterprise projects for students to practice. [4] But teacher should pay attention to the selection of the project to adapt to the students' current stage ability. This can not only train students' practical ability and cooperative spirit, but also enable students to understand the needs of electronic technology in the current development stage of society. Arrange reasonable competition, and make students feel appropriate sense of urgency can stimulate students' potential. Arrange different competition environment more can fully mobilize the enthusiasm of the students pursuing success, constantly bring new challenges to students.

\section{USE SITUATIONAL TEACHING TO ENHANCE STUDENTS' INTEREST}

We firmly reject the teaching method of "cramming education" which under the influence of traditional education concept. [5] How to design a lively and interesting professional course, this has a high requirement for teachers' professional quality and teaching ability. In the classroom, the teaching situation should be set reasonably, and the situational introduction closely related to the reality should be used to stimulate the students' exploration spirit so that students can participate spontaneously and actively in the classroom. [6] The theory of knowledge studied in the books , the ultimate goal is to apply to practice. It is also cater to the characteristics of the electronic technology course, "combine theory with practice". In practice, it can better consolidate the theoretical knowledge that has been learned, and also cultivate students' logical thinking and expand knowledge. At the same time, the knowledge that students gain is not limited to textbooks, but spread to a broader, deeper level. In practice, we will encounter various situations. To improve students' professional skills, we must practice repeatedly in practice, and find problems, solve problems until master methods in practice. [7]Improve the ability to solve problems in a real situation and cultivate a good attitude. In the situation of teaching, using the theory of electronic technology to analyze material closely related to our reality. It can enhance students' thinking logic, and trains the student to have a good idea to solve the problem of professional. In addition, teachers can also encourage students to set up some communities, holding a lot of related professional knowledge contests. According to their interests formed interest groups of different research direction, it can exercise the students' comprehensive ability.

\section{SELECT TEACHING CONTENT AND DO TEACHING TREATMENT}

Starting from the current situation of some secondary vocational education schools, many teachers choose teaching content and design courses according to the teaching materials. Some teacher even make course depend entirely on the teaching materials. This has weakened the personality of the course to a certain extent. At present, the teaching materials of education in China still haven't achieved the ideal quality. There are two main defects. One is that some content is too esoteric but not practical, which is beyond the comprehension of students. Some of the content is too crude and antiquated, and the techniques taught in it have not adapted to the needs of today's society. The other is that the design of textbook is not very readable and can not adapt to the characteristics of students in vocational schools. [8]In this context, the selection of teaching content is particularly important. Schools should also strengthen to the cultivation of teachers, improving teachers' understanding of the new curriculum and teaching theory. Teachers should be flexible in teaching content to improve the quality of curriculum and teaching. Secondary vocational schools arrange some experienced teachers to develop school-based teaching materials is also an important entry point of teaching content reform. Teachers can combine the content of school-enterprise cooperation, design teaching content that combines local characteristics and corporate characteristics, and help students better handle the relationship between theory and practice. Secondary vocational and technical schools should set up curriculum development team and curriculum research team, responsible for establishing reasonable school-based curriculum and school-based teaching materials. In this way, make the course more accord with students' characteristics and needs of society, in order to achieve the purpose of establishing and perfecting the schoolbased curriculum development system.

\section{IMPROVE THE LEVEL OF TEACHERS AND IMPROVE THE QUALITY OF TEACHING STAFF}

The professional level of teachers can directly affect the quality of teaching and the professional quality of students. Therefore, secondary vocational and technical schools should pay attention to improving the faculty level of teachers of electronic technology. On the one hand, it is possible to enhance the electronic faculty strength of the school by recruiting talents with strong professionalism or social practicality through increased preparation; On the other hand, it is also necessary to let existing professional teachers participate in the latest and most advanced professional training in electronic technology. It is necessary not only to strengthen the faculty level in theoretical knowledge, but also to learn the new technologies and new skills applied by the current society. At the same time, increase cooperation and exchanges with other high-level institutions to improve the teaching level of teachers. It is possible to hold regular competitions in teaching skills so that teachers of various professions can exchange learning and teaching methods. Reasonable planning of competition rules, awards and other details can help teachers improve their teaching skills more efficiently, in order to achieve the goal of cultivating outstanding teachers. Reforming the existing 
teacher evaluation mechanism is also an important factor that affects the success of education reform. The reform measures should be conducive to the teachers' own development needs, and help the teachers to feel at ease and concentrate on education and teaching. Schools must have teacher development plans. The education authorities should pay attention to the development of teachers and continuously improve the business and quality of teachers to meet the teaching requirements. It is necessary to reform the assessment mechanism so that the teaching team can develop in a healthy and upward direction. The rapid development of electronic technology has led to a surge in demand for electronic technology talents, which has brought many students development opportunities. Secondary vocational and technical schools should seize this opportunity, vigorously develop the electronic technology profession, and combine the actual development of the region, constantly grasp the demand dynamics of electronic technology talents, improve the professional curriculum, so that professional teaching content and technology development status can be as close as possible. At the same time, efforts should be made to enhance teachers' own level, improve teaching methods, and explore more scientific and more suitable teaching methods for electronic technology professional education for secondary vocational and technical schools.

\section{STRENGTHEN QUALITY EDUCATION AND IMPROVE STUDENTS' QUALITY}

From the student level to analyze the problems existing in the current vocational colleges, we can find the following: Firstly, the curriculum does not meet the cognitive rules of students, ignoring the cultivation of students' quality. The age group of secondary vocational college students is a crucial period for the formation of world outlook and values. The liberal arts courses in ordinary high schools has a positive impact on students' world outlook and values. However, in reality, vocational schools do not offer courses in politics, history, and law, and there is no scientific evaluation system. It is precisely the lack of teaching in these courses that students cannot form a correct world outlook, outlook on life and values in time. Secondly, secondary vocational education schools should pay attention to the needs of enterprises for talents. Enterprises need not students with comprehensive professional knowledge, but workers with higher comprehensive qualities and certain professional capabilities. The comprehensive qualities mentioned here include a positive world outlook and values, good habits, discipline concepts, collaborative spirit and so on. Most of the vocational schools ignore education in these areas.

In view of this, the proposal for secondary vocational and technical schools is to scientifically set up various courses and strengthen quality education. The quality that citizens should have refers to the morality, knowledge, function, and emotion that are compatible with the national legal system and political system. Through quality education, students have a strong sense of patriotism and social responsibility; have full understanding and respect for morality; consciously abide by civilized etiquette; have a sense of awe in law, and thus consciously regulate individual behavior, with good discipline, habits and unity The spirit of collaboration, strong initiative and innovation. Through quality education, students have a strong sense of patriotism and social responsibility, and have a full understanding and respect for morality. Thus consciously regulate individual behavior, form a good spirit of discipline, habits and solidarity, strong initiative and innovation. In the case of three-year secondary vocational education, in all courses, the quality education curriculum should occupy more than one-half of the proportion, and the continuity of education should be three years. In addition, in the teaching of electronic technology courses, quality education can also be reflected. Breaking the quality education mainly depends on the class teacher, so that all teachers become quality education practitioners. Let students receive quality education and quality education at all times.

\section{CONCLUSION}

Due to the wide-ranging needs of the society for electronic technology talents, the training of secondary vocational and technical schools is particularly important. To clarify the content and orientation of electronic technology courses can help promote the reform of education. By optimizing the course structure, transforming the teaching idea, and strengthening the "integration of theory and practice", we will cultivate the comprehensive and diversification electronic technology talents.

\section{REFERENCES}

[1] Rolf Becker, David Glauser. Vocational Education and Training, Vocational Baccalaureate or Academic High School? An Empirical Analysis of Social Selective Transitions to Upper Secondary Education in the German-Speaking Part of Switzerland[J]. Swiss Journal of Sociology,2018,44(1).

[2] Forster Andrea G,Bol Thijs. Vocational education and employment over the life course using a new measure of occupational specificity.[J]. Social science research,2018,70.

[3] Csaba Csíkos, Zsuzsa Kovács, Orsolya Kereszty. Hungarian vocational education teachers' views on their pedagogical knowledge and the information sources suitable for their professional development[J]. Empirical Research in Vocational Education and Training,2018,10(1).

[4] Martin Lackéus. Does entrepreneurial education trigger more or less neoliberalism in education?[J]. Education + Training,2017,59(6).

[5] Nikolai Sergeev. High-priority directions of modernization of university education in innovational society[J]. International Journal of Educational Management,2017,31(1).

[6] Stan Lester. Sequential schooling or lifelong learning? International frameworks through the lens of English higher professional and vocational education[J]. Education + Training,2018,60(2).

[7] Uswatun Qoyyimah. Policy implementation within the frame of schoolbased curriculum: a comparison of public school and Islamic private school teachers in East Java, Indonesia[J]. Compare: A Journal of Comparative and International Education,2018,48(4).

[8] Mauricio Farías,María Paola Sevilla. Effectiveness of Vocational High Schools in Students' Access to and Persistence in Postsecondary Vocational Education[J]. Research in Higher Education,2015,56(7). 